Article

\title{
The Effectiveness of Marketing Communication and Importance of Its Evaluation in an Online Environment
}

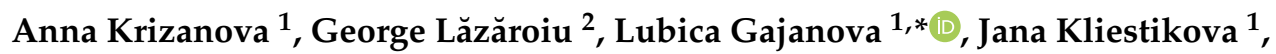 \\ Margareta Nadanyiova ${ }^{1}$ (D) and Dominika Moravcikova ${ }^{1}$ \\ 1 Department of Economics, The Faculty of Operation and Economics of Transport and Communications, \\ University of Zilina, Univerzitna 1, 01026 Zilina, Slovakia; anna.krizanova@fpedas.uniza.sk (A.K.); \\ jana.kliestikova@fpedas.uniza.sk (J.K.); margareta.nadanyiova@fpedas.uniza.sk (M.N.); \\ dominika.moravcikova@gmail.com (D.M.) \\ 2 Department of Economic Sciences, Spiru Haret University, Bucharest 030045, Romania; \\ phd_lazaroiu@yahoo.com \\ * Correspondence: lubica.gajanova@fpedas.uniza.sk; Tel.: +421-41-513-3237
}

Received: 31 October 2019; Accepted: 30 November 2019; Published: 9 December 2019

\begin{abstract}
Online marketing communication covers a wide area and thus promotes an extensive reach of advertising to a broad audience. Hotels can achieve certain goals through online communication, mainly an increase of hotel awareness; an improvement of their image; and an increase in the level of customer satisfaction and trust, or brand loyalty. Measurement of the effectiveness of communication tools in the online environment is still a challenge, whether in the academic world or in the business world, mainly due to the complexity of this process. The main objective of this paper is to propose a methodology for implementing an indicator suitable for the evaluation of the effectiveness of online communication activities in the Slovak hotel industry. It uses analysis of the current usage of online marketing communication activities from the perspective of hotel service providers. The methodology should be applicable to support decision-making and actively support the sustainable development of hotels. In order to achieve the objective of the paper, the authors conducted a marketing survey focused on online marketing communication by Slovakian hotels to determine their use and to map the current state or methods of evaluating their effectiveness. Results of the research suggest that hotels in Slovakia perceive evaluating marketing communications online as being important, regardless of the size, length of operation, budget, and class of the hotel. They prefer financial metrics because they are a de facto manifestation of the traditional approach towards investment evaluation. The results also showed that return on investment is the most common metric for evaluating the investments of online communication activities, and that respondents expressed the highest level of confidence in this metric as well. In line with the results, we have proposed return on investment (ROI) as the most appropriate metric applicable in evaluation of the effectiveness of online communication tools.
\end{abstract}

Keywords: online marketing; effectiveness; return on investments; hotel industry; Slovakia

\section{Introduction}

Competitive pressures on hotels and additional problems caused by the slow pace of economic growth are triggering a push for greater efficiency and effectiveness. As a result, marketing activities have become an integral part of business operations, as they have an impact on the current and future success of hotels. Their use is a continuous process in which the key task is to follow new trends and respond flexibly to surrounding changes [1]. This also applies to marketing communication, 
in which using an adequately selected combination of communication tools leads to long-term customer relationships and the sustainable development of hotels.

The unprecedented growth of online marketing has not only changed the way people interact, it has also changed the way in which businesses attract and retain their consumers. The Internet has become an innovative marketing tool by providing travel information and a place to conduct online transactions [2]. The informational nature of tourism products means that the Internet, which offers a global reach and multimedia capabilities, is an increasingly important tool for promoting and distributing tourism services [3]. The increasing number of new communication channels has increased the need for hotels to pay attention to the effectiveness of these activities. Therefore, they must determine whether they wish to use communication tools efficiently or to merely take advantage of their benefits [4].

Classic forms of marketing media are becoming a thing of the past [5]. Online marketing communication and its new forms provide a wider coverage area that promotes a better reach of advertising to a wider audience. The forms of marketing communication available online are much faster to use than offline communication tools, as the advertiser has more space online to provide more information to a potential customer at a relatively low cost. The effectiveness of new forms of online marketing communication is enhanced by the continuous development of ads in the online environment, which can be created using the many analytic tools available [6]. Therefore, measuring the effectiveness of these communication tools in an online environment is a very complex process, especially in a constantly changing environment where new marketing resources are being developed every day. However, determining the effectiveness of different forms of online marketing communication is still a major challenge for the academic and business worlds. Since online marketing is completely different from traditional marketing approaches, traditional marketing theories and practices may not be applicable to these types of communication tools.

Based on the aforementioned discussion, we have analysed the current usage of online marketing communication activities by hotel service providers. Based on the results, the main objective was to identify or propose a suitable methodology for evaluating the effectiveness of online communication activities that would be specific to the Slovak hotel industry and would be useful to support decision-making relating to the sustainable development of hotels.

\section{The Current State of the Slovak Hotel Industry}

Despite minor oscillations, European and global tourism have been experiencing significant growth overall. European tourists currently have high purchasing power, as well as a tendency to travel frequently, which is why Europe continues to be the leader in global tourism flows [7]. The hotel industry in Central and Eastern Europe has been registering growth in all key indicators. The number of tourists as well as the occupancy rates have returned to pre-global financial crisis conditions or have even surpassed them [8].

Slovakia has all of the necessary prerequisites for the development of tourism-natural environments, a convenient geographical location, historical monuments, a strong cultural heritage, etc. However, it currently does not make sufficient use of these assets. The trend towards the development of active tourism and the need for a hotel industry catering for it has been a challenge for Slovakia. Slovakia in recent years has been receiving a lower share of tourists from Western European countries and an increasing share of visitors from former socialist countries. Most tourists come to Slovakia from the Czech Republic, Hungary, Poland, Germany, Austria, the Netherlands, and Ukraine. In terms of visitor composition, tourists visiting Slovakia are most commonly 35-45 years of age and have a lower middle class income. The most common reasons to visit Slovakia are transit, business or study trips, visits to family, shopping tourism, vacation stays, cultural/sightseeing trips, skiing and spa trips. The average number of overnight stays is three nights [9]. The share of tourism in the Slovak GDP is approx. $2.5 \%$ and does not reach the EU countries average (more than $5 \%$ ). The low percentage is the result of several factors such as incomplete and unrelated services, unsatisfactory infrastructure 
(mainly transport), lack of qualified staff in services (insufficient level of foreign language skills), a low level of services that is inconsistent with price levels, and low awareness and promotion [10].

A positive phenomenon in the context of tourism and hotel industry promotion in Slovakia is the adoption of the official logo "Good Idea Slovakia" in 2016, which is focused not only on represent Slovakia but also on supporting domestic tourism, accommodation facilities, restaurants, organizations, and providers of tourism services. The Act No. 415/2013 Coll. on Promotion of Tourism as amendment is also considered a challenge to support Slovak tourism, as well as new forms of online marketing strategies [11]. It aims to motivate tourism entities to ensure the coordination of activities, i.e., destination management in regions and areas of tourism, in other words, a system element that is significantly absent in Slovakia.

In Slovakia, 38 tourism organizations have been established since 1 January 2011. The aim of these organizations is to create and implement the concept of tourism development; to create and implement marketing and promotion of tourism for the members at home and abroad; to promote the common interests of the members; to promote cultural, social, and sporting life; and to preserve natural and cultural heritage [10]. A major challenge in the field of marketing communication for the development of domestic tourism and hotel industry is the financial contribution to the recreation of employees. Employers have provided contributions to employees since 01/2019, in accordance with the Article 152a of the Act No. 311/2001 Coll. on Labour Code as amendment [12].

As the primary role of marketing communication is to influence the consumer to purchase a product or service, this marketing mix tool is under considerable pressure to achieve demonstrable business results in forms such as influencing sales of products and services, increasing brand awareness, or getting customer information. In order to reduce this pressure, hotels are looking for new solutions. Marketing communication is a tool of marketing mix, which is characterized by constantly emerging new trends. The enormous boom of the online environment gives hotels multiple options to communicate with existing or potential customers [13]. Because of a large number of communication tools available in the online environment, hotel managers need to find the most effective ones.

\section{Literature Review}

Businesses in all sectors pay close attention to the concept of effectiveness. The evaluation of effectiveness in the field of Slovak and foreign literature is being scientifically researched from several points of view depending on the scientific focus of authors. The advancement and importance of communication technologies in recent decades have led to the growth and development of the business environment and intensified competition [14-16]. Businesses have been forced to seek new ways to meet customer demands. As a result, there is a growing awareness among businesses about the need for effectiveness of heterogeneous business activities [17]. To explain this, a marketing perspective is taken to explain the fact that companies achieve their objectives by satisfying their customers with greater effectiveness than their competitors [4]. Consequently, measures designed to assess the effectiveness of business activities should reflect the specific activities and types of products and services offered [18]. It is also important to determine theoretical knowledge of effectiveness and its evaluation, which would be most suitable for its implementation in marketing communication.

In economic theory, it is possible to determine two basic terms in connection with any investment appraisal—effectiveness and efficiency. These terms have a semantic base, mainly in English scientific sources. Efficiency is defined as the ratio between input and output, or between the achieved results and the incurred costs [19]. It follows that the efficiency refers to the economic aspect of heterogeneous means invested in business activities, i.e., is interpreted as economy. Economy for marketing communication is defined as the minimization of costs incurred in order to achieve the stated communication goal, i.e., efficiency is the degree of achievement of the relevant goal of marketing communication activity [20]. In terms of the number of input and output variables, efficiency is expressed as the ratio of inputs and outputs that are achieved in a conversion per production unit with a result equal to or greater than one [21]. 
The definitions of effectiveness are determined differently. The concept of effectiveness is based on the word effect, that is, the effect of providing outputs in the form of products and services resulting from the consumption of production factors (inputs) to the target audience [22]. It can be stated that it is the ability to produce the desired outputs with a rational usage of available inputs. The importance of effectiveness in terms of the number of input and output variables lies in a production system based on either maximizing outputs (output-oriented effectiveness) or minimizing inputs (input-oriented effectiveness) [21]. In the marketing and communication field, the interpretations of this meaning could include the relationship between the given communication goals and real impacts on business results, i.e., the ratio of desired and achieved.

In connection with the issue of marketing communication, it is also necessary to define its modern forms-creative, emotional, innovative, and integrated communication [23]. This means that effectiveness is an intellectual effort, as well as an attitude based on that effort, which must be constantly measured to ensure commercial success [24]. However, it is important to note that effectiveness is not only a measure of market success, but also a measure of operational excellence or productivity. This involves minimizing costs and improving operating margins. On the other hand, effectiveness is linked to the ability of a company to design a unique model of accepting business opportunities through the exchange of relationships. Focusing on efficiency and neglecting effectiveness can lead to a temporary profitability. Otherwise, focusing on effectiveness and lack of efficiency can lead to unprofitable growth [25-27]. The company should therefore maintain an optimal level of efficiency and effectiveness (the indicators that will lead to sustainable profitability and business growth $[28,29]$ ).

\subsection{Marketing Effectiveness and Importance of Its Evaluation}

The essence of marketing effectiveness is particularly useful in any business, as it assumes better business stability, long-term profit growth, increased customer satisfaction, competitive advantage, and business sustainability [21,30-35]. A study on the evaluation of marketing effectiveness has shown that businesses with higher marketing effectiveness also achieve higher overall business effectiveness compared to competitors in the market where marketing effectiveness is not a priority [36]. The assessment of marketing effectiveness is an integral part of a comprehensive business performance evaluation that helps companies to implement a marketing strategy by providing a general view of business performance [37,38]. The aim of evaluating marketing effectiveness is to analyse the interrelationships between marketing activities and overall business performance [39]. It is very important that the concept of marketing and its effectiveness contribute to the overall functioning of the business and are not an isolated function. This means that the objectives of evaluating marketing effectiveness and business objectives should be mutually supportive, especially in the areas of meeting customer needs; stimulating, developing, and increasing sales; and assessing the impact on overall business effectiveness.

There are several conceptual measures defining marketing effectiveness that are based on academic research. Drucker, as the first author dealing with the issue of marketing effectiveness, states that the basis for the success of marketing activities and processes is to do the right things, which means, to do things in an effective way [40]. Marketing effectiveness, as reported by Walker and Ruekert, refers to the results of business programs in relation to the resources used to implement them [41]. More specifically, Clark states this. According to him, effectiveness refers to the relationship between marketing results (marketing outcomes) and efforts or means introduced into marketing (marketing inputs) [42]. Measuring effectiveness is a matter of increasing importance in developing strategic plans, evaluating the achievement of marketing goals, and rewarding managers [43-45].

Other authors also discussed the issue of marketing effectiveness. According to them, the effectiveness in terms of marketing represents a comparison of marketing outputs and marketing inputs, i.e., efforts in relation to the outcomes of business programs and the resources used, i.e., the suitability of marketing communication programs with existing business structures. This means that they have investigated the extent to which marketing activities can meet the business goals [46]. 
This scientific study was extended by Mavondo, who examined marketing effectiveness only in the short term. He presented the positive impact of marketing effectiveness on the financial performance of a company, which resulted in increased market share, sales, gross margin, and even successful launch of new products on the market [34].

Other authors have built on previous studies and even expanded them and presented marketing effectiveness as a measure of how a company can gain a higher market share over competition in advertising and promotion field. They dilated their research to optimize marketing spending through marketing effectiveness to achieve even better results for both short- and long-term goals [31]. Gao's study was based on the basic formulation of effectiveness, doing the right thing by comparing marketing effectiveness with the goals formulated in the market strategy of the business [47]. Another study also examined marketing efficiency, but the outcome was to define marketing effectiveness as a long-term process that was aiming to create value based on business resources for marketing activities and competitive advantage [32]. In Slovakia, the authors, who addressed the issue of marketing effectiveness, defined in their studies the concept of marketing effectiveness as the quality with which managers optimize expenditures in order to achieve better results for companies in the short- and long-term, i.e., optimize the quality of marketing spending so that businesses achieve their goals in any time period analysed [33].

There are various reasons to carry out regular measurements of the effectiveness of a business. These reasons may include, especially in the marketing environment, as follows:

- If something cannot be changed, it cannot be understood;

- If something cannot be understood, it cannot be checked;

- If something cannot be checked, it cannot be improved;

- If results cannot be measured, success cannot be distinguished from failure;

- If success cannot be seen, it cannot be evaluated;

- If success cannot be evaluated, failure is likely to be evaluated;

- If failures are not recognized, old errors will be repeated and resources wasted [48].

\subsection{Effectiveness and Evaluation of Marketing Communication in the Online Environment}

The use of Internet technologies in marketing communication is gaining in importance [49]. It is also a fact that the most revenues are generated through online marketing communications by using personalization, multimedia integration, and real-time interactions [50-52].

The importance of effectiveness of marketing communication in the online environment is also multiplied by the number of scientific publications dealing with this issue in the renowned databases, namely, Web of Science (1990) and Scopus (2059), for the period from 2004 to 2018 (Figure 1). However, it should be noted that the number of scientific articles and studies includes all synonyms of online marketing, i.e., digital marketing, internet marketing, and e-marketing.

The effectiveness of the evaluation of any marketing tools is also assumed by the fact that only a comprehensive evaluation can move companies into further development of marketing activities [53]. Thus, the effectiveness of marketing tools becomes the basic dimension of a company's performance and the basic pillar for its sustainable development [30]. 


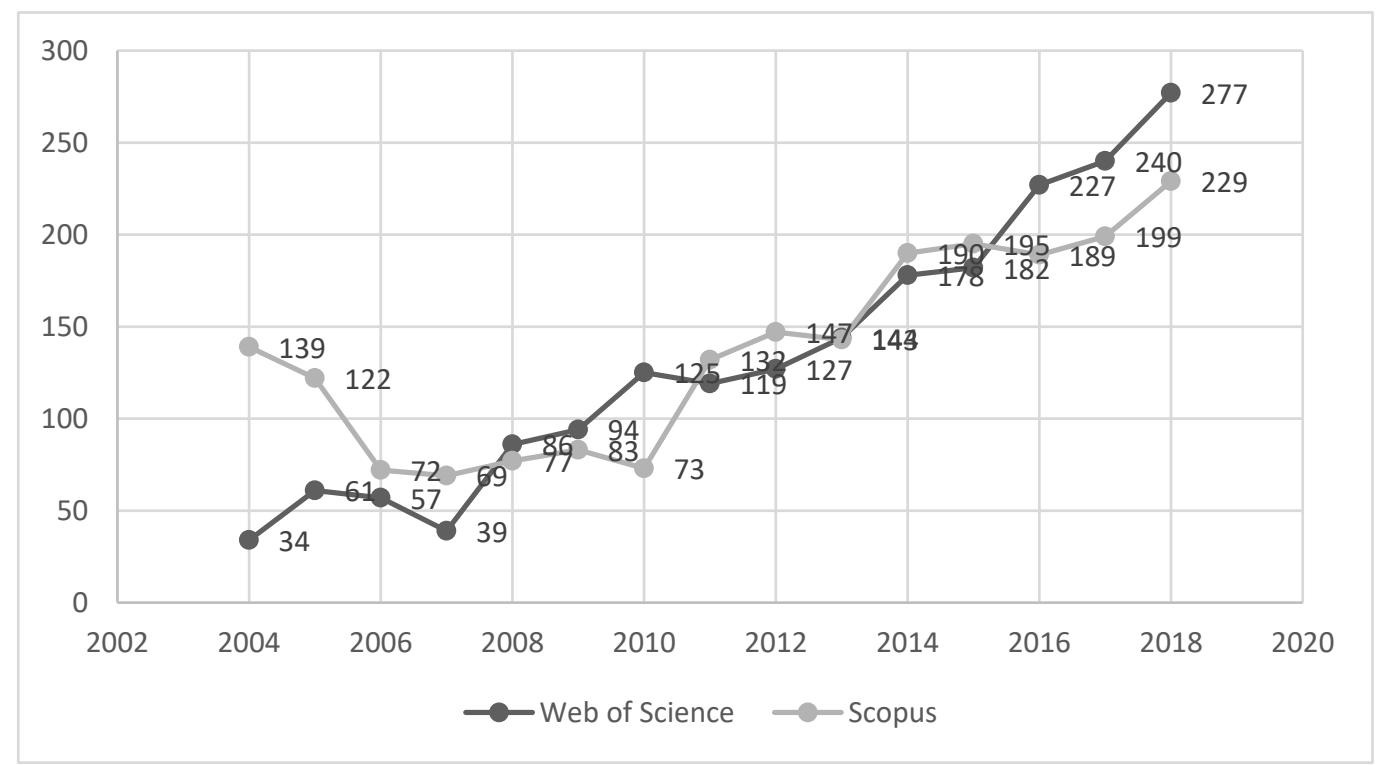

Figure 1. Number of scientific articles and studies from the Web of Science and Scopus databases on the effectiveness of online marketing communication.

\section{Materials and Methods}

Demonstrating effectiveness in marketing has never been so difficult. There are many factors to consider: pressure on marketing budgets, transforming media environments and channels, the impact of technology, changing consumer behavior, and so on. Such a dynamic environment is both a challenge and an opportunity. Demonstrating the tangible effectiveness of communication campaigns is becoming increasingly important for marketers. Measuring of effectiveness has become a key issue in the marketing departments of many companies over the last decade [54]. In his study, IBM identified the measurability of marketing activities as one of the three key areas for future development. The findings of the study show that the ability to evaluate marketing investments could be one of the main ways to restore credibility to the marketing department [55].

Another report showed that the evaluation of the effectiveness of communication activities is perceived as significant by the contracting authorities. However, it was surprising to find that $43 \%$ of marketers do not measure the return on investment in their communication activities. Rather, the results of the study confirmed the use of standard evaluation methods. More than $90 \%$ of respondents evaluate the effectiveness of communication campaigns, and $53 \%$ of respondents usually use the return on investment (ROI) indicator for evaluation. So, most marketing professionals track campaign results, but only half of them in financial terms. The $47 \%$ of marketers do not monitor the financial impact of their campaigns. The study showed that typically large companies with long-term existence and higher budgets for communication activity of the company implement the evaluation of effectiveness. Only $41 \%$ of respondents are evaluating all campaigns, more than half of the respondents focus on criteria of effectiveness for selected campaigns only, and $7 \%$ of respondents report that they evaluate their campaigns only exceptionally [56].

IBM study also identified increasing pressure on marketing departments based on qualitative research. IBM considers the ability to quantify and analyse the financial results of marketing investments and, above all, to present the conclusions of marketing department activities throughout the organization as a key task [55]. The measuring of effectiveness is also expected to be a challenge in studies of Reglix [57,58].

Another survey also revealed a significant need for improving data use, measuring online marketing, and evaluating marketing return on investment. In addition, the survey also focused on the degree of business satisfaction regarding ability to measure return on marketing investments. Up to $41 \%$ of businesses in the US are satisfied with their ability to measure marketing ROI through 
proper leadership and perseverance. Their knowledge of their marketing return on investment allows them to manage marketing spending decisions. Only $43 \%$ of organizations make their marketing budgets based on an analysis of marketing return on investment. In contrast, $68 \%$ of businesses base their marketing budgets partly on historical spending and $28 \%$ on their own instincts. When making decisions about specific marketing expenses, up to $21 \%$ of businesses make all or most of those spending decisions without metrics. Instead of marketing return on investment, executives continue to use many traditional metrics, such as brand preference, shopping intent, and willingness to recommend [59].

These facts together with the theoretical background form the basis of our research. We assumed that hotel management feels pressure in the form of the ability to quantify the return on investment spent on the online form of communication even in the conditions of the Slovak Republic. That is why we asked in the realized research whether hotels evaluate the effectiveness of all forms of online marketing communication used. Additionally, we asked whether there is a certain type of hotel (based on size, life time, budget size, and hotel class) that would perform that assessment to a greater extent. Another focus of the research was on the benefits and metrics of evaluating the effectiveness of online marketing communications. In the end, we asked whether hotels were generating an interest in new methodology to assess the effectiveness of online marketing activities, the creation of which is the main objective of this paper.

Based on the theoretical research and analysis of secondary data and with a view to achieving the objective of the paper, following research questions and hypotheses were formulated:

- Research question 1: Do hotels assess the effectiveness of all forms of online marketing communication that they apply?

Hypothesis 1a. The effectiveness of the applied forms of online marketing communication is insufficiently monitored by lower-class hotels.

Hypothesis $\mathbf{1 b}$. The effectiveness of the applied forms of online marketing communication is insufficiently monitored by hotels with a lower budget in this field.

Hypothesis 1c. The effectiveness of the applied forms of online marketing communication is insufficiently monitored by hotels with a shorter existing (lifetime).

Hypothesis 1d. The effectiveness of the applied forms of online marketing communication is insufficiently monitored by hotels of a smaller size.

- Research question 2: Do hotels perceive the benefits of evaluating the effectiveness of online marketing communication?

Hypothesis 2. There is no statistical dependence between the perception of the benefits of evaluating the effectiveness of online marketing communication and the evaluation itself.

- Research question 3: What metrics do hotels use to evaluate the effectiveness of online marketing activities?

- Research question 4: Is the level of metrics used to assess the effectiveness of online hotel marketing activities sufficient?

Hypothesis 3. There is no statistical dependence between the types of metrics for assessing the effectiveness of online hotel marketing activities and their sufficient level.

- Research question 5: Are hotels interested in implementing a new methodology to assess the effectiveness of online marketing activities? 
In order to meet the main objective of the paper, the conceptual scheme of research elaboration shown in Figure 2 was used. The scheme is based on theoretical knowledge from secondary research and data obtained from primary research, and illustrates the connection of the research questions and hypotheses to individual factors.

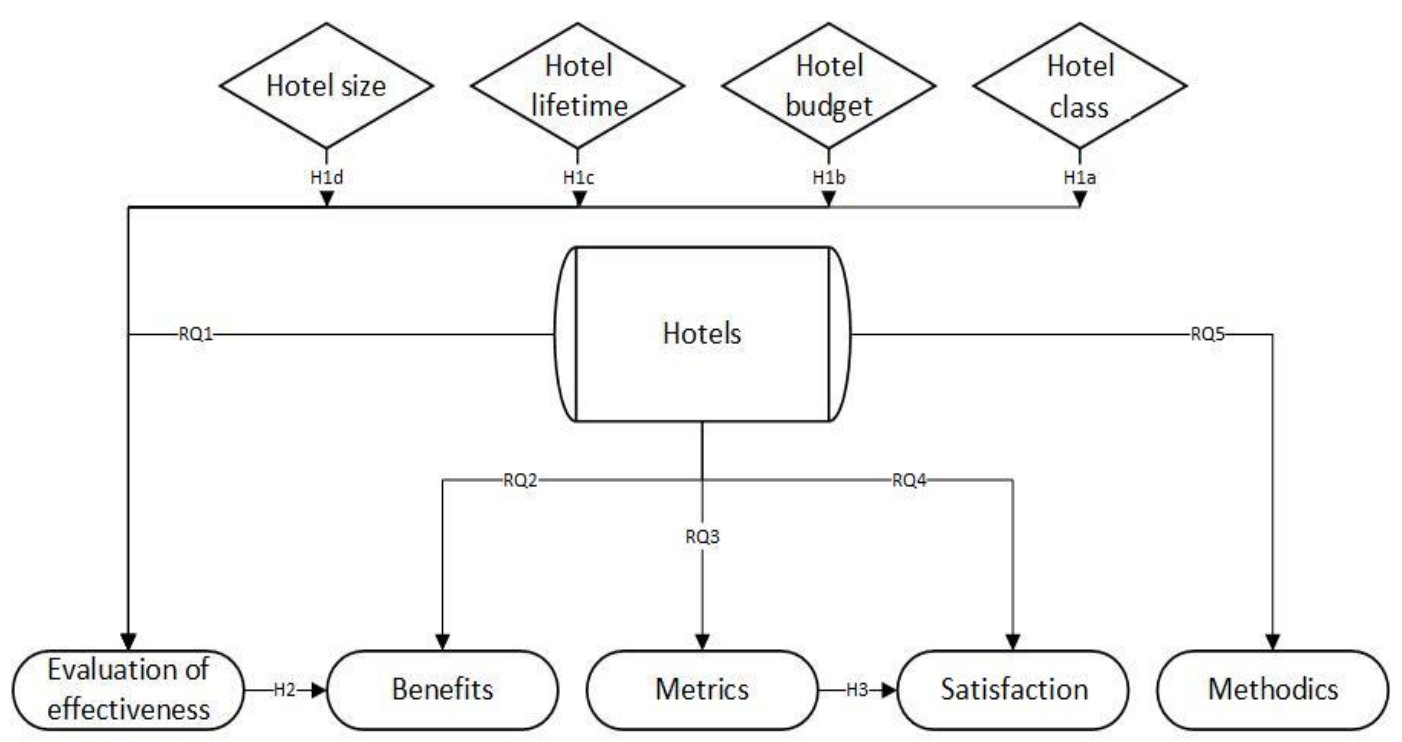

Figure 2. Conceptual scheme of research elaboration.

In order to meet the objective of the paper, the authors conducted a marketing survey focused on online hotel marketing communication in the conditions of Slovakia to determine the level of its use in the practice and to map the current state or methods of evaluating of its effectiveness. According the results, the authors proposed $\mathrm{ROI}$ as the most appropriate metric applicable in the evaluation of effectiveness of online communication tools.

In the survey, the size of the population was determined based on data obtained from the organizational statistics of the Statistical Office of the Slovak Republic. The population consists of economic units classified according to their primary economic activity-based on the SK NACE, group "55.10.0 Hotels and Similar Accommodation". For the purposes of the paper, we dealt with accommodation facilities of a hotel type, as these facilities are divided into classes according to the quality of services and technical equipment. Pursuant to Decree of the Ministry of Economy of the Slovak Republic no. $277 / 2008$, a class is determined as meeting the minimum requirements for accommodation facilities, quality, and scope of services adequate to the class, which is marked with stars from the lowest class $\left(^{*}\right)$ to the highest class $\left({ }^{* * * *}\right)$. The size of the base population is 803 economic units, respectively, hotels (December 2017). As 313 hotels participated in the marketing survey, the minimum sample size (260 hotels) was met. The answers of respondents to the questions based on the determined confidence level (95\%) and confidence interval (5\%) can be considered as relevant. In the case of a marketing survey, the questionnaire method was chosen; the questionnaires were distributed by e-mail.

The questionnaire consists of three parts. The first part is focused on the importance, benefits, and use of online marketing communication. The second part deals with the investments into online marketing communication and perception of the effectiveness of online marketing communication. The objective was to find out whether hotels were evaluating the effectiveness of online marketing communication tools, and whether they would be interested in the proposed methodology of effectiveness evaluation. The last part concerns the general profile of the respondent, i.e., class of the hotel, its size, lifetime, annual turnover, etc.

The method of statistical hypothesis testing was chosen for the research. It is one of the most important statistical inference procedures. The role of statistical inference is to decide on the basis of information on the available choices whether to accept or reject certain hypotheses with respect 
to the basic sample set. In order to do so, we proceeded in accordance with the methodology of statistical hypothesis testing [60]. Because the primary data in this research is of a nominal nature, the test statistic is the Chi-square test of independence. To calculate the test statistic for the hypothesis, IBM SPSS Statistics software was used. This software also calculates the correlation coefficient. In this case, because the nominal variables are being examined in the number of $3+\times 2+$, it was appropriate to investigate the strength of the dependence between the variables using the Cramer's V measure of association [51,60,61].

The correspondence analysis is a multivariate graphical technique designed to explore relationships among categorical variables. When the study variables of interest are categorical, correspondence analysis is an appropriate technique to explore the relationships amongst variable response categories and can play a complementary role in data analysis [62]. The use of correspondence analysis must therefore be preceded by the testing of hypotheses on the independence of observed characters [63]. Correspondence analysis is conducted using the IBM SPSS Statistics software, too. The essence of this analysis is the transformation of points of the multidimensional space, which represent the examined categories, into a space of lower dimension, most often in the plane ( 2 dimensions). This transformation is unambiguous and allows us to focus on revealing a certain type of relationship between categories (variables). We evaluate the transformation quality based on the rates derived from the total inertia.

\section{Results}

Mostly small businesses (74.4\%) were involved in the survey to determine the level of use of online marketing communication activities and to map the level of the evaluation of the effectiveness of these activities. In addition, $21.1 \%$ of medium-sized enterprises, $4.2 \%$ of micro-enterprises, and $0.3 \%$ of large enterprises participated in the survey. In terms of classifying the hotel, four-star hotels formed the largest group (44.1\%), followed by three-star hotels and motels (39\%), two-star hotels and motels $(10.9 \%)$, and five-star hotels (4.4\%). Hotels and motels with one star $(1.6 \%)$ had the smallest representation $(1.6 \%)$. In terms of the period of existence of hotels, most hotels and motels exist from $11-15$ years $(46 \%)$ and $16-20$ years (39\%).

To answer the first research question, we asked the respondents whether they evaluated the effectiveness of all forms of online marketing communication, which they used in the practice. The effectiveness of all online forms is regularly evaluated by $17.3 \%$ of hotels, often in $27.1 \%$, sometimes $20.8 \%$, and rarely $4.1 \%$. Up to $30.7 \%$ of hotels do not evaluate the effectiveness at all.

The subject of research was also the reason for not monitoring performance and evaluating the effectiveness. Respondents stated reasons as high evaluation costs, current situation is sufficient, lack of resources (employees, funds, and process data), and evaluation of effectiveness only in some forms of online marketing communication. Subsequently, we used the primary data from this question to test the statistical hypotheses H1a to H1d. The results are shown in Table 1.

Table 1. Chi-square test of independence of hypotheses 1a-1d.

\begin{tabular}{ccccc}
\hline Hypothesis & $\boldsymbol{p}$-Value & Significance Level & Reliability Interval & Acceptance/Rejection of the Hypothesis \\
\hline \multirow{3}{*}{ H1a } & \multirow{2}{*}{0.3456} & 0.01 & $99 \%$ & Rejection \\
& & 0.05 & $95 \%$ & Rejection \\
& 0.10 & $90 \%$ & Rejection \\
\hline \multirow{3}{*}{ H1b } & \multirow{2}{*}{0.1172} & 0.01 & $99 \%$ & Rejection \\
& & 0.05 & $95 \%$ & Rejection \\
\hline \multirow{2}{*}{ H1c } & \multirow{2}{*}{0.1766} & 0.10 & $90 \%$ & Rejection \\
\hline \multirow{2}{*}{ H1d } & 0.01 & $99 \%$ & Rejection \\
& \multirow{2}{*}{0.0793} & 0.10 & $95 \%$ & Rejection \\
& & 0.01 & $90 \%$ & Rejection \\
\hline
\end{tabular}


The test proved there is no significant variable that would reveal the descriptive factor of the hotel, which more often performs an evaluation of the effectiveness of all forms of online marketing communication used. Only in the case of the size factor was the existence of the dependence of the examined variables confirmed, but only at a low level of reliability interval, which indicates a very low dependence.

Another explored aspect of the survey was to point out the benefits of evaluating the effectiveness of online marketing communication. Respondets perceive monitoring of effectiveness positively, as $59.1 \%$ of respondents perceive the significance of this activity, $24.3 \%$ are in favour of the fact that monitoring of the performance and effectiveness is rather meaningless, and only $16.6 \%$ do not see it as meaningful.

The resulting further aspect of the research was to find out the existence/absence of statistical dependence between the perception of the benefits of evaluating the effectiveness of online marketing communication and the evaluation itself. The test statistics are presented in Tables 2 and 3.

Table 2. Chi-Square Tests-Hypothesis 2.

\begin{tabular}{cccc}
\hline & Value & df & Asymptotic Significance \\
\hline Pearson Chi-Square & $177.391 \mathrm{a}$ & 12 & 0.000 \\
\hline Likelihood Ratio & 201.996 & 12 & 0.000 \\
\hline N of Valid Cases & 313 & & \\
\hline
\end{tabular}

Table 3. Symmetric Measures-Hypothesis 2.

\begin{tabular}{cccc}
\hline & & Value & Approximate Significance \\
\hline \multirow{2}{*}{ Nominal by Nominal } & Phi & 0.753 & 0.000 \\
& Cramer's V & 0.435 & 0.000 \\
\hline \multicolumn{2}{c}{ N of Valid Cases } & 313 & \\
\hline
\end{tabular}

A significance level was determined at 0.05 and corresponded to a $95 \%$ confidence interval. Based on the comparison of the significance level with the $p$-value (Asymptotic Significance), the null hypothesis was rejected and the alternative hypothesis confirmed, i.e., there is a statistically significant relationship between the variables examined. The intensity of the dependence of the variables according to Cramer's V (0.435) indicates a moderate dependency. Therefore, we can say that hotels that evaluate the effectiveness of online marketing communication have proven to be more aware of the benefits of doing so.

To answer other research questions, respondents were asked for information on their own evaluation method. Only those who stated that they were using a metric responded to the level of adequacy of its results. The most commonly used metric is ROI $26.2 \%$. Other metrics are Google Analytics (20.1\%), customer satisfaction survey $(8.9 \%)$, monitoring statistics $(8.6 \%)$, and an analysis of demand for tourism products $(6.7 \%)$. Up to $23.3 \%$ of hotels reported missing the form (procedure) to assess the effectiveness of online marketing communications, and $6.2 \%$ did not monitor the effectiveness of any online communication form. Subsequently, we used the primary data from these questions to test statistical hypothesis 3 . The calculated test statistics are presented in Tables 4 and 5 .

Table 4. Chi-Square Tests-Hypothesis 3.

\begin{tabular}{cccc}
\hline & Value & Df & Asymptotic Significance \\
\hline Pearson Chi-Square & $44.014 \mathrm{a}$ & 12 & 0.000 \\
\hline Likelihood Ratio & 42.837 & 12 & 0.000 \\
\hline N of Valid Cases & 217 & & \\
\hline
\end{tabular}


Table 5. Symmetric Measures-Hypothesis 3.

\begin{tabular}{cccc}
\hline & & Value & Approximate Significance \\
\hline \multirow{2}{*}{ Nominal by Nominal } & Phi & 0.450 & 0.000 \\
& Cramer's V & 0.260 & 0.000 \\
\hline \multicolumn{2}{c}{ N of Valid Cases } & 217 & \\
\hline
\end{tabular}

A significance level was determined at 0.05 and corresponded to a $95 \%$ confidence interval. Based on the comparison of the significance level with the $P$-value (Asymptotic Significance), the null hypothesis was rejected and we can confirm an alternative hypothesis, so there is a statistical dependence between the variables examined (types of metrics to assess the effectiveness of online marketing activities of hotels and their sufficient level). The intensity of the interdependence of variables by the Cramer's V measure of association (0.260) indicates low dependence. Based on the existence of dependence between the variables, it makes sense to examine the internal structure of the contingency table by the correspondence analysis. The results are shown in Figure 3.

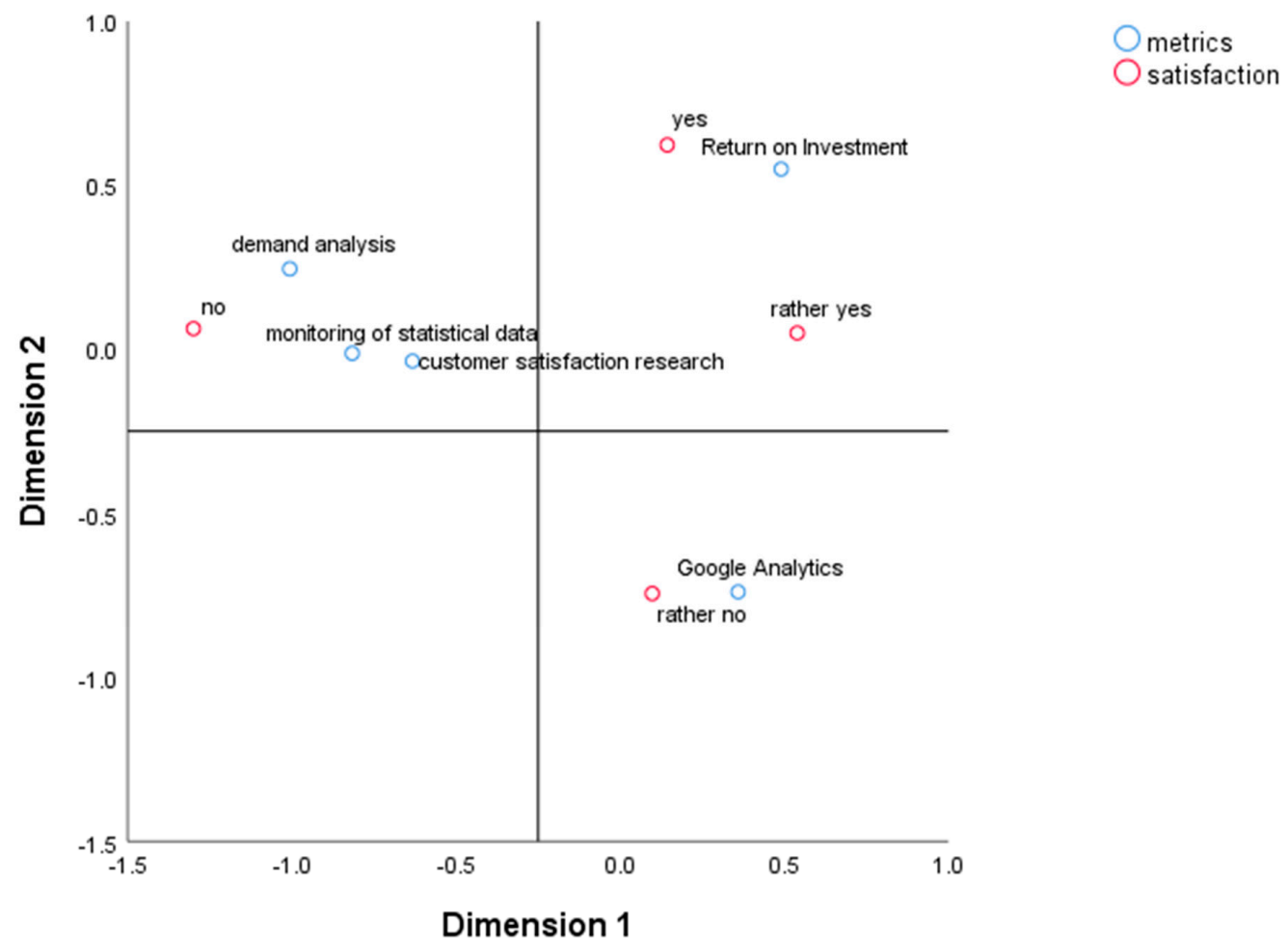

Figure 3. Correspondence map.

To visualize the correspondence map, it is necessary to reduce the extracted dimensions to only two, so that the map can be displayed in a two-dimensional view. Interpretation of the correspondence map that we have obtained in this way is relatively simple. The position of the line and column categories indicates which categories are related (corresponding) to each other. The metrics, namely, the Questionnaire Survey of Customer Satisfaction, Monitoring of Statistical Data, and Analysis of Demand for Tourism Products are very similar in terms of satisfaction assessment. The metrics ROI and Google analytics are specific in this case. They are sufficiently distant from other metrics, so they do not show common characteristics in terms of satisfaction. As for the individual levels of satisfaction, only two of them are similar (Yes and Rather Yes), as they are in a common quadrant of the map. Google analytics is captured on the map closest to the satisfaction category Rather No Strongly Disagree. The ROI is assigned to the category of satisfaction assessment at the level Yes. The vertical 
axis shows the distinction between the ROI and Google analytics from other metrics. This axis captures the distinction of expressing total dissatisfaction with metrics from other levels of satisfaction. The most important result of the correspondence map is that the ROI metric clearly shows the highest satisfaction rate.

In another question, respondents were asked whether they could imagine applying a particular procedure or form to assess the effectiveness of online marketing communication in their activities if it existed. Up to $89.8 \%$ expressed interest.

\section{Discussion}

In evaluating the effectiveness of online marketing communication, hotels identify and then examine results and explore opportunities for improving and modifying this effectiveness.

\subsection{Benefits of Evaluating the Effectiveness of Online Marketing Communication}

Observing and evaluating the effectiveness of online communication tools leads to identification of how well hotels are implementing communication tools, and if something is wrong, it determines the barriers and possibilities to overcome this deficiency in the future [64].

Such information helps any hotel to understand whether online marketing communication is achieving its goals and whether the implementation of online communication strategy is moving in the right direction. The goals that a hotel can achieve through its online communication, e.g., are increasing hotel awareness; improving its image, awareness, and trust; increasing the level of customer satisfaction and loyalty; and differentiating itself from the competition or increasing the number of hotel guests [65-67].

Many hotels consider forms of online marketing communication only as a pro-forma promotion without a return on funds. The survey conducted in conditions of Slovakia has showed that up to $30.7 \%$ of hotels do not evaluate the effectiveness of all used forms of online communication at all. This is contrary to studies and surveys that have showed that a thoroughly refined marketing strategy and an interest in innovations in marketing communications can bring hotels and other businesses a favourable financial outcome, long-term growth, and a stable position in the hotel product market.

Most (59.1\%) of the hotels surveyed are aware of the benefits of evaluating the effectiveness of online marketing communication, namely,

- It contributes to a more exhaustive redesign of the marketing communication strategy and leads to increased trust among marketing staff;

- It leads to the integration of communication between a hotel and its customers (since elaborated effectiveness assessment procedures lead to easier communication and create a clearer picture of a business strategy), more effective communication with customers, and better targeting of online communication tools;

- It increases alignment with not only marketing goals but also business goals, marketing strategy, and employee loyalty;

- It increases the share of successfully implemented changes-revised feedback will not only increase the likelihood of success, but will also speed up the process of making the necessary changes;

- It leads to better problem prediction and optimization of online communication portfolios;

- It makes it easier for marketing staff to continuously perceive the impact of introduced changes on individual marketing processes, increasing the effectiveness of processes and working time.

Based on the results of the survey, it can even be argued that hotels that evaluate the effectiveness of online marketing communication are demonstrably more aware of the benefits of doing so. The objective of the contribution was justified by the demonstration of these benefits. The hotels also showed an enormous interest (89.8\%) in implementing this kind of methodology in their activities. 


\subsection{Identifying the Most Appropriate Metric for the Effectiveness Evaluation}

Return on investment can be used as the most appropriate metric to measure the effectiveness of marketing activities, because it simply refers to the idea that something of value has resulted from an investment of time, energy, or money [68]. In the financial approach, ROI is usually reduced to a formula, which is calculated simply by subtracting the cost of an investment from the income received from the investment, divided by the same investment cost. ROI as a return on funds invested in marketing activities can be considered as one of the most important methods of measuring marketing effectiveness. It can be assumed that businesses still prefer financial appreciation of return to non-financial appreciation $[53,69]$. Justifying the value of the intervention of companies in online environment and knowing what the usefulness or benefits are of marketing in this area have been priorities over the years [70]. As this trend has increased, sellers have had to make the right decisions about key aspects of new forms of online marketing communication and determine how to measure their effectiveness through return on investment [71,72]. Due to the particularities of the tourism sector, $\mathrm{ROI}$ is constituted as suitable for the measurement of the effectiveness of online marketing actions, since the subjectivity that runs through the entire tourism process encourages the inclusion of measurement tools that take this fact into account [73].

We have identified ROI as the most appropriate metric for developing a methodology based on the attitude of several authors dealing with this issue $[49,52,56,59,74,75]$, as this method is the most suitable for measuring the success of communication activities. ROI should also be used as an optimization method [52]. Based on the survey, we have found that the most frequent response of respondents regarding the choice of method by which they assess the success and subsequent optimization of forms of online marketing communication is ROI (26.2\%). Moreover, the assumption that the use of ROI clearly shows the highest hotel satisfaction is also confirmed.

\subsection{Methodology of Implementing ROI for the Effectiveness Evaluation}

The proposed methodology uses the basic functions of Microsoft Excel to eliminate barriers to performance monitoring and evaluation of the effectiveness of online marketing activities reported by hotels in the Slovak Republic, namely, high evaluation costs, lack of resources (employees, funds, and process data), and evaluation of effectiveness only in some forms of online marketing communication. Based on the non-confirmed hypotheses $1 \mathrm{a}-1 \mathrm{~d}$, this methodology is generally applicable in all hotels in Slovakia. The methodology is able to track all hotel-determined online marketing communication metrics and other data points in one visual, central location-dashboard. In this way, it provides a high-level view of working in the online environment, helping the hotel management to make quick decisions and keep up-to-date information on all online forms of communication used.

The visual nature of the dashboard simplifies work and complicated data. It provides an immediate view of current status or performance in real time, as it is made up of tables, metrics, and numbers. Using a dashboard, hotel management can understand what works and what does not work, and proactively seeks to optimize every form of online marketing communications. The calculation model has a relatively simple structure (see Figure 4), as it consists of only one sheet. This sheet titled "ROI Calculation" includes not only a partial return on investment of each online form of marketing communication, but also an overall return on investment for a hotel online marketing campaign. In addition, this sheet is the only sheet in which hotel management can make changes and adjustments to the inputs and calculation items used in each form of online marketing communication. Dashboard is divided into three parts: basic information; data about forms of online marketing communication; and input and output characteristics, including numeric data. 


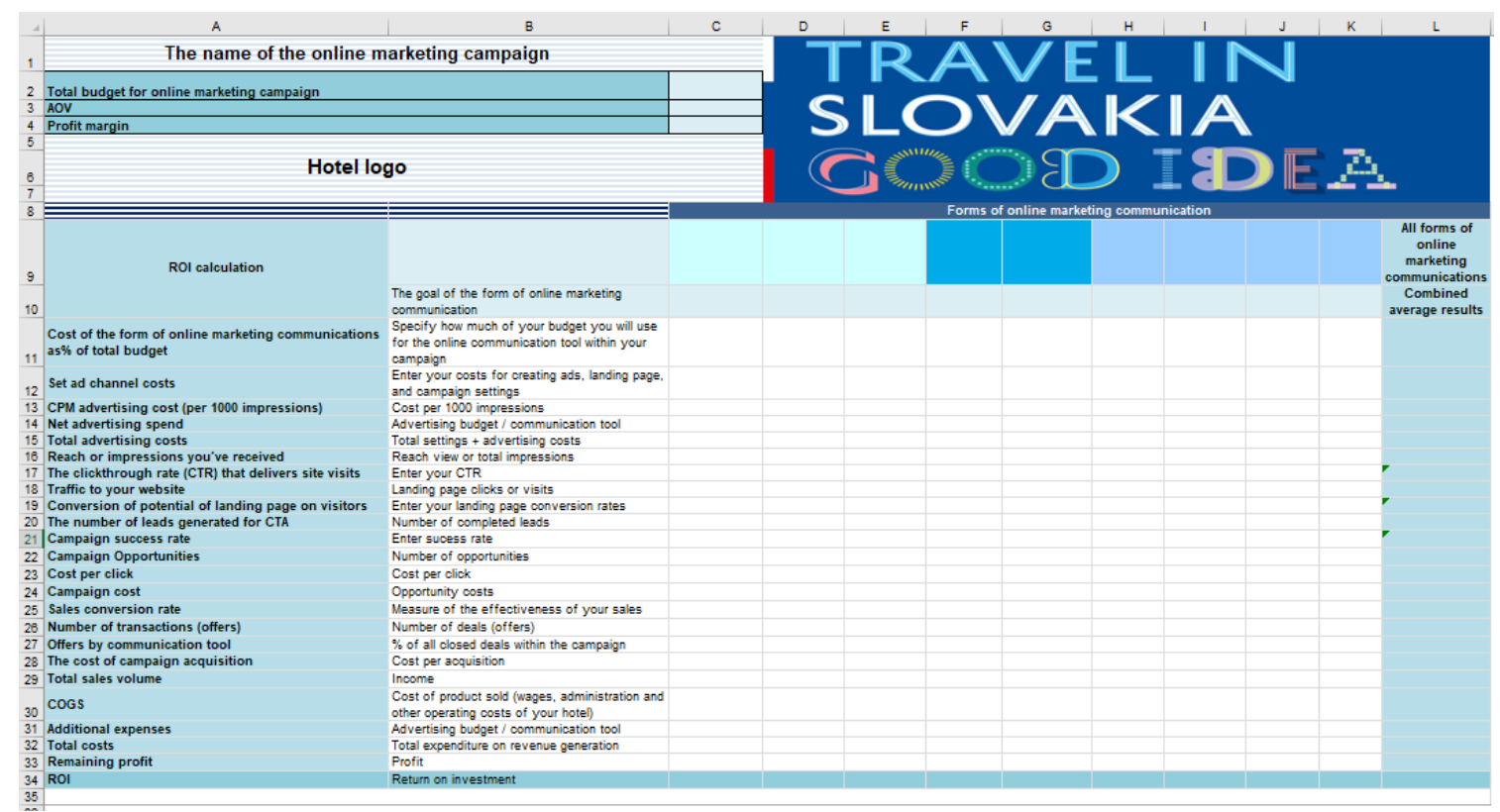

Figure 4. Methodology of implementing return on investment (ROI) for the effectiveness evaluation.

The first part of the ROI calculation of the online marketing campaign contains information about the name of the online marketing campaign, respectively, about the goal that the evaluated forms of online marketing communication should achieve. In addition, the hotel management needs to fill in the data about the total budget for the online marketing campaign (cell C2), the average order value (AOV) (average amount of value generated by each online activity by an average customer (cell C3)), and the profit margin expressed as a percentage of a hotel's profit from sales of its products and services (cell C4). Among other things, hotels can insert their own logo in this calculation, which will be placed to the left of the wording "Travel in Slovakia Good Idea" (a project funded by the European Union for the promotion of tourism in the Slovak Republic and the brand Slovakia). The second part of the ROI calculation concerns the determination of the various forms of online marketing communication that are identified by a hotel's management (line 9, columns $C$ to L). In line 10, management will indicate the specific goal of each form of online marketing communication used. Inserting the input and output characteristics of selected forms of online marketing communication, including their numerical data, relates to the calculation of ROI for individual selected forms of online marketing communication overall. Column A (ROI calculation) lists the names of input and output characteristics, which were selected on the basis of several professional foreign studies dealing with the issue of online marketing communication effectiveness $[30,43,46,47,50,56,59,76]$. In addition, in the column $B$, the user can identify the specific input and output characteristics of the forms of online marketing communication. The columns $\mathrm{C}$ to $\mathrm{L}$ (quantity depends on the number of the forms of online marketing communication used) contain numerical values of each input and output characteristic, including the relationships needed to quantify the ROI of these communication tools and overall.

\section{Conclusions}

During the 21st century, the issue of measuring and evaluating the effectiveness of online marketing communication has become very topical and significant. Indeed, the harsh competitive environment of the hotel industry tends to influence hotels to use redundant marketing communication tools. It is increasingly necessary to reassess their effectiveness. The evaluation of marketing communication tools, especially their online forms, is no longer an option but a necessity. Since the phenomenon of the effectiveness of marketing communication tools is undoubtedly considered as a ratio of return on marketing revenues to marketing costs, the guidelines for their measurement are insufficient and fall short of the requirements of the modern hotel industry. 
In the light of the above, the main objective of the contribution was to propose a methodology suitable for evaluating the effectiveness of online communication activities in the Slovak hotel industry that would be a sufficient element supporting the decision-making process in the context of the sustainable development of hotels. In order to meet the objective of the paper, a marketing survey was conducted in which hotels in the Slovak Republic were the object of research, and its purpose was to determine the level of use of online marketing communication activities and to map the status of evaluating their effectiveness. Results of the research suggest that hotels in Slovakia perceive the importance of evaluating marketing communications in the online environment, regardless of hotel size, lifetime, budget, and class. They prefer financial metrics de facto, as they are a manifestation of the traditional approach to investment evaluation. The results also showed that ROI is the most common metric for evaluating investments of online communication activities, and respondents expressed the greatest confidence in this metric as well. The results thus confirm that theories that emphasize financial appreciation and rank ROI as the most appropriate metric to measure the effectiveness of marketing activities are also applicable in the Slovak Republic. Additionally, from the perspective of the particularities of the tourism sector, ROI is constituted as suitable for measuring the effectiveness of online marketing actions, since the subjectivity that runs through the entire tourism process encourages the inclusion of measurement tools that take this fact into account.

According to the above, the suggested methodology takes a form of the proposed Excel dashboard, and as the most appropriate metric, ROI was identified. The performance of ROI calculation in the field of online marketing communications is beneficial not only for hotels but also for other business entities for two primary reasons. Firstly, ROI is very well known among the management staff of various companies; secondly, the assessment of ROI in online marketing communication helps to determine not only partial returns but also overall marketing returns. ROI ensures the measurement of the results of online communication activities in a participatory way, thus extending the goals of hotel marketing communication. It is calculated in a way that includes heterogeneous types of data, depending on the specific form of online marketing communication. It helps to increase the relevance and effectiveness of the work of any hotel management, as it allows one to consider how particular online communication activities contribute to achieving communication goals of hotels.

Time and geographical constraints can be considered as the main limits of the suggested methodology. These restrictions were especially reflected in the selection of respondents-only enterprises operating in Slovakia were chosen in the statistical sample. This limitation can be removed if the results of the research are considered as a relevant solution and the results achieved are subject to subsequent verification in the international environment. If these barriers were removed, results that are more accurate could be achieved. Another limitation of the research is the established scale in some issues. There may be some distortions in the responses to whether they are using defined financial and non-financial metrics. Therefore, it could be appropriate to apply the Likert scale. Other research in the field of measuring the effectiveness of marketing activities would be interesting to compare the relevance of solutions and the verification of the results achieved in the international environment. In addition to the international comparison, further research could be focused on another sector industry and thus find out information on evaluating the effectiveness of marketing communication in other industries in Slovakia as well.

Author Contributions: Conceptualization, A.K.; Formal analysis, G.L. and A.K.; Investigation, D.M.; Methodology, L.G.; Project administration, A.K. and J.K.; Software, L.G. and M.N.; Supervision, G.L. and J.K.; Writing一original draft, L.G. and D.M.; Writing-review and editing, M.N.

Funding: This contribution is a partial output of the project APVV-15-0505: Integrated Model of Management Support for Building and Managing the Brand Value in the Specific Conditions of the Slovak Republic.

Conflicts of Interest: The authors declare no conflict of interest. 


\section{References}

1. Drugău-Constantin, A. Emotional and Cognitive Reactions to Marketing Stimuli: Mechanisms Underlying Judgments and Decision Making in Behavioral and Consumer Neuroscience. Econ. Manag. Financ. Mark. 2018, 13, 46-50. [CrossRef]

2. McMahan, C.; Hovland, R.; McMillan, S. Online Marketing communications: Exploring online consumer behavior by examining gender differences and interactivity within internet advertising. J. Interact. Advert. 2009, 10, 61-76. [CrossRef]

3. Mikiashvili, N.; Lobzhanidze, N. Green innovations and economic policy in small economies. Forum Sci. Oeconomia 2017, 5, 29-40. [CrossRef]

4. Kotler, P.; Wong, V.; Saunders, J.; Armstrong, G. Moderní Marketing, 4th ed.; Grada Publishing: Praha, Czech Republic, 2007; ISBN 978-80-247-1545-2.

5. Danaher, P.J.; Rossiter, J.R. Comparing perceptions of marketing communication channels. Eur. J. Mark. 2011, 45, 6-42. [CrossRef]

6. Ližbetinová, L.; Štarchoň, P.; Lorincová, S.; Weberová, D.; Pruša, P. Application of cluster analysis in marketing communications in small and medium-sized enterprises: An empirical study in the Slovak Republic. Sustainability 2019, 11, 2302. [CrossRef]

7. Ivanovic, S.; Milenovsky, A.; Milojica, V. Croatian Tourism and Hospitality Industry: Current State and Future Developmental prespectives. UTMS J. Econ. 2015, 6, 293-305.

8. Gurová, Z. Investori Sa Spoliehajú Na Výkonnost' Stredoeurópskych Hotelov. Available online: http: //www.cushmanwakefield.sk/sk-sk/news/2017/03/cee-hosipitality (accessed on 15 November 2019).

9. Križek, F.; Neufus, J. Moderní Hotelový Management; Grada: Praha, Czech Republic, 2014; ISBN 8024748355.

10. Ministry of Transport and Construction of the Slovak Republic. Stratégia Rozvoja Cestovného Ruchu do Roku 2020. Available online: https://www.mindop.sk/ministerstvo-1/cestovny-ruch-7/legislativa-akoncepcne-dokumenty/koncepcne-dokumenty/strategia-rozvoja-cestovneho-ruchu-do-roku-2020 (accessed on 15 November 2019).

11. Travel in Slovakia Good Idea. Available online: https://slovakia.travel/ (accessed on 15 November 2019).

12. Act No. 311/2001 Coll. on Labour Code as Amendment. Available online: https://zakony.judikaty.info/ predpis/zakon-311/2001 (accessed on 8 December 2019).

13. Kramarova, K. Integrovaná Marketingová Komunikácia a Model Hodnotového Spektra. In Proceedings of the International Scientific Conference on Globalization and its Socio-Economic Consequences, Rajecke Teplice, Slovakia, 30 September-2 October 2008.

14. Oláh, J.; Karmazin, G.; Pető, K.; Popp, J. Information technology developments of logistics service providers in Hungary. Int. J. Logist. Res. Appl. 2018, 21, 332-344. [CrossRef]

15. Zapletalová, Š. Competitive strategies of the SMEs: Empirical evidence from the Czech Republic. Forum Sci. Oeconomia 2017, 5, 9-26. [CrossRef]

16. Shpak, N.; Odrekhivskyi, M.; Doroshkevych, K.; Sroka, W. Simulation of Innovative Systems under Industry 4.0 Conditions. Soc. Sci. 2019, 8, 202. [CrossRef]

17. Nagy, J.; Oláh, J.; Erdei, E.; Máté, D.; Popp, J. The Role and Impact of Industry 4.0 and the Internet of Things on the Business Strategy of the Value Chain-The Case of Hungary. Sustainability 2018, 10, 3491. [CrossRef]

18. Mala, D.; Bencikova, D. Innovations of a green product. Ekon. Spektrum 2018, 12, 64-74. [CrossRef]

19. Samuelson, P.A.; Nordhaus, W.D. Ekonomie; Nakladatelství Svoboda: Praha, Czech Republic, 2008; ISBN 978-80-205-0590-3.

20. Paulík, D. Základy Financií a Meny; Inštitút aplikovaného manažmentu: Trenčín, Slovakia, 2012; ISBN 978-80-896-0006-9.

21. Stavarek, D.; Šulganová, J. Analýza efektívnosti slovenských bánk s využitím Stochastic Frontier Approach. Ekon. Rev. 2009, 12, 27-34. [CrossRef]

22. Synek, M. Manažérska Ekonomika; Grada Publishing: Praha, Czech Republic, 2003; ISBN 80-247-0515-X.

23. Šindler, P. Event Marketing: Jak Využít Emoce v Marketingové Komunikaci; Grada Publishing: Praha, Czech Republic, 2003; ISBN 978-80-2476-371-2.

24. Molnár, Z. Efektionost Informčních Systému; Grada: Praha, Czech Republic, 2000; ISBN 80-7169-410-X.

25. Valaskova, K.; Kliestik, T.; Kovacova, M. Management of financial risks in Slovak enterprises using regression analysis. Oecon. Copernic. 2018, 9, 105-121. [CrossRef] 
26. Weissova, I.; Kollar, B.; Siekelova, A. Rating as a Useful Tool for Credit Risk Measurement. In Proceedings of the 4th World Conference on Business, Economics and Management (WCBEM), Ephesus, Turkey, 30 April-2 May 2015.

27. Oláh, J.; Kovács, S.; Virglerova, Z.; Kovacova, M.; Popp, J. Analysis and comparison of economic and financial risk sources in SMEs of the Visegrad Group and Serbia. Sustainability 2019, 11, 1853. [CrossRef]

28. Zerihun, T.B.; Shekhar, V. The effect of marketing effectiveness and efficiency on the marketing performance of medium and large financial service enterprises in Ethiopia. International J. Multidiscip. Manag. Stud. 2011, 1, 29-46.

29. Sroka, W.; Szanto, R. Corporate Social Responsibility and Business Ethics in Controversial Sectors: Analysis of Research Results. J. Entrep. Manag. Innov. 2018, 14, 111-126. [CrossRef]

30. Daukševičiuté, I.; Valainis, A.; Vilkaitè, N. Conceptualization of the effectiveness of marketing tools. Intelekt. Ekon. 2011, 5, 200-211.

31. Nwokah, G.; Ahiauzu, A.I. Managerial competency and marketing effectiveness in corporate organizations in Nigeria. J. Manag. Dev. 2008, 27, 858-878. [CrossRef]

32. Žostautiené, D.; Vaičiulenaité, I. Coherence model between marketing culture and marketing effectiveness. Econ. Manag. 2010, 15, 874-879.

33. Solčanský, M.; Šimberová, I. Measurement of marketing effectiveness. Econ. Manag. 2010, 15, 755-759.

34. Mavondo, F.T.; Chimhanzi, J.; Stewart, J. Learning orientation and market orientation. Eur. J. Mark. 2004, 39, 1235-1263. [CrossRef]

35. Pramanik, R.; Prakash, G. Marketable surplus and marketing efficiency of vegetables in Indore district. J. Agric. Econ. 2010, 7, 84-93.

36. Kožená, M.; Chládek, T. Company competitiveness measurement depending on its size and field of activities. Procedia Soc. Behav. Sci. 2012, 58, 1085-1090. [CrossRef]

37. Bartáková, G.; Gubíniová, P. Udržatel'ný Marketingový Manažment; IAM Press: Trenčín, Slovakia, 2015; ISBN 978-80-89600-08-3.

38. Stonkute, E.; Vveinhardt, J.; Sroka, W. Training the CSR Sensitive Mind-Set: The Integration of CSR into the Training of Business Administration Professionals. Sustainability 2018, 10, 754. [CrossRef]

39. Andrijauskiene, M.; Dumciuviene, D. National culture as a determinant of firms' innovative performance. Forum Sci. Oeconomia 2018, 6, 47-67. [CrossRef]

40. Drucker, P. Management: Tasks, Responsibilities, Practices; Harper Row: Michigan, MI, USA, 1974; ISBN 978-00-6011-092-5.

41. Ruekert, R.W.; Walker, O.C. Marketing's interactions with other functional units: A conceptual framework and empirical evidence. J. Mark. 1987, 51, 1-19. [CrossRef]

42. Clark, B.H. Marketing Performance Measures: History and Interrelationships. J. Mark. Manag. 1999, 15, 711-732. [CrossRef]

43. Ittner, C.D.; Larcker, D.F. Are nonfinancial measures leading indicators of financial performance? An analysis of customer satisfaction. J. Account. Res. 1998, 36, 1-35. [CrossRef]

44. Kmecova, I. The processes of managing human resources and using management methods and techniques in management practice. Ekon. Spektrum. 2018, 12, 44-54. [CrossRef]

45. Mura, L.; Haviernikova, K.; Machova, R. Empirical results of entrepreneurs' network: Case study of Slovakia. Serb. J. Manag. 2017, 12, 121-131. [CrossRef]

46. Ambler, T.; Kokkinaki, F.; Puntoni, S.; Riley, D. Assessing market performance: The Current State of Metrics. Available online: http://facultyresearch.london.edu/docs/01-903.pdf (accessed on 25 October 2019).

47. Gao, Y. Measuring marketing performance: A review and a framework. Mark. Rev. 2010, 10, 25-40. [CrossRef]

48. Halachmi, A. Performance measurement in only one way of managing performance. Int J. Product. Perform. Manag. 2005, 54, 502-516. [CrossRef]

49. Meilă, A.D. Regulating the Sharing Economy at the Local Level: How the Technology of Online Labor Platforms Can Shape the Dynamics of Urban Environments. Geopolit. Hist. Int. Relat. 2018, 10, 181-187. [CrossRef] 
50. Fahmy, M.M.; Ghoneim, A.I. The impact of interactivity on advertising effectiveness of corporate websites: A mediated moderation model. Int. J. Mark. Res. 2016, 8, 41-55. [CrossRef]

51. Durica, M.; Svabova, L. Improvement of company marketing strategy based on Google search results analysis. Proc. Econ. Financ. 2015, 26, 454-460. [CrossRef]

52. Hoffman, D.; Fodor, M. Can you measure the ROI of your social media marketing? MIT Sloan. Manag. Rev. 2010, 52, 41-49.

53. Valaskova, K.; Kramarova, K. Analysis of a market performance in the European Union and Slovakia. In Proceedings of the 15th International Scientific Conference on Globalization and its Socio-Economic Consequences, Rajecke Teplice, Slovakia, 7-8 October 2015.

54. Da Gama, A.P. An Expanded Model of Marketing Performance. Mark. Intell. Plan. 2011, 29, 643-661. [CrossRef]

55. IBM. Od rozšíření vlivu po jeho posílení. Available online: https://docplayer.cz/3746558-Poznatky-z-globalnistudie-marketingovych-reditelu-rozsireni-vlivu-po-jeho-posileni-shrnuti-pro-vedouci-pracovniky.html (accessed on 17 November 2019).

56. Obluk, O. Hodnocení Efektivitykomunikačních Kampaní. Available online: https://docplayer.cz/2180743Hodnoceni-efektivity.html (accessed on 17 November 2019).

57. Regalix. TOP B2B Marketing Channels and Tactics. Available online: http://www.marketingprofs.com/ charts/2015/26985/top-b2b-marketing-channels-and-tactics (accessed on 17 November 2019).

58. Regalix. State of B2B Social Media Marketing. Available online: http://www.regalix.com/wp-content/ uploads/2016/10/State-of-B2B-Social-Media-Marketing-2016.pdf (accessed on 17 November 2019).

59. NYAMA. Marketing ROI in the Era of Big Data. Available online: https://www.iab.com/wp-content/uploads/ 2015/05/2012-BRITE-NYAMA-Marketing-ROI-Study.pdf (accessed on 17 November 2019).

60. Rimarčík, M. Štatistika Pre Prax; Marián Rimarčík, 2007; ISBN 978-80-969813-1-1.

61. McHugh, M.L. The Chi-square test of independence. Biochem. Med. 2013, 23, 143-149. [CrossRef]

62. Sourial, N.; Wolfson, C.; Zhu, B.; Quail, J.; Fletcher, J.; Karunananthan, S.; Bandeen-Roche, K.; Béland, F.; Bergman, H. Correspondence analysis is a useful tool to uncover the relationships among categorical variables. J. Clin. Epidemiol. 2010, 63, 638-646. [CrossRef]

63. Král', P. Viacrozmerné Štatistické Metódy So Zameraním Na Riešenie Problémov Ekonomickej Praxe; Univerzita Matej Bela: Banská Bystrica, Slovakia, 2019; ISBN 978-80-8083-840-9.

64. Gúčik, M. Marketing Cestovného Ruchu; Dali BB, s. r. o.: Banská Bystrica, Slovakia, 2011; ISBN 978-80-89090-85-3.

65. Maráková, V. Marketingová Komunikácie v Cestovnom Ruchu; Wolters Kluwer: Bratislava, Slovakia, 2016; ISBN 978-80-8168-394-7.

66. Rădulescu, A. Users' Social Trust of Sharing Data with Companies: Online Privacy Protection Behavior, Customer Perceived Value, and Continuous Usage Intention. Contemp. Read. Law Soc. Justice 2018, 10, 137-143. [CrossRef]

67. Stuchlý, J.; Jambal, T.; Ližbetinová, L. Loyalty programs and customer preferences. In Proceedings of the 32nd International Business Information Management Association Conference, IBIMA 2018-Vision 2020: Sustainable Economic Development and Application of Innovation Management from Regional Expansion to Global Growth, Seville, Spain, 15-16 November 2018.

68. Jiménez, M.A.S.; Correia, M.B.; de Matos, N. Analysis of social networks as an instrument of communication in the tourist destinations of Algarve. Rev. GEINTEC 2018, 8, 4476-4494. [CrossRef]

69. Bragg, S.M. Business Ratios and Formulas: A Comprehensive Guide; John Wiley Sons: New York, NY, USA, 2012; ISBN 978-1118169964.

70. Haddow, G. Academic library use and student retention: A quantitative analysis. Libr. Inf. Sci. Res. 2013, 35, 127-136. [CrossRef]

71. Kingma, B.; Mcclure, K. Lib-value: Values, outcomes, and return on investment of academic libraries, phase III: ROI of the Syracuse University Library. Coll. Res. Libr. 2015, 76, 63-80. [CrossRef]

72. McMullen, A. The value of values. Bottom Line 2013, 26, 4-6. [CrossRef]

73. Bonilla, J. Nuevas tendencias del turismo y las tecnologías de información y las comunicaciones. Tur. Y Soc. 2013, 14, 33-45. 
74. Wu, J. Calculating the ROI for Business Intelligence Projects. Available online: http://www.informationmanagement.com/news/2487-1.html (accessed on 29 November 2019).

75. Buhalis, D.; Mamalakis, E. Social media return on investment and performance evaluation in the hotel industry context. In Proceedings of the International Conference, Lugano, Switzerland, 3-6 February 2015; Tussyadiah, I., Inversini, A., Eds.; Springer: Cham, Switzerland, 2015.

76. Rust, T.R.; Lemon, K.N.; Zeithaml, V.A. Return on Marketing: Using Customer Equity to Focus Marketing Strategy. J. Mark. 2004, 68, 109-127. [CrossRef]

(C) 2019 by the authors. Licensee MDPI, Basel, Switzerland. This article is an open access article distributed under the terms and conditions of the Creative Commons Attribution (CC BY) license (http://creativecommons.org/licenses/by/4.0/). 